\title{
Effects of open drainage ditch design on bacterial and fungal communities of cold waterlogged paddy soils
}

\author{
Shanlian Qiu ${ }^{1}$, MK Wang ${ }^{2}$, Fei Wang ${ }^{1}$, Jichen Chen ${ }^{1}$, Xiaoyan $\mathrm{Li}^{3}$, Qinghua $\mathrm{Li}^{1}$, \\ Cheng Lin ${ }^{1}$, Xinjian Lin ${ }^{1}$ \\ ${ }^{1}$ Soil and Fertilizer Institute, Fujian Academy of Agricultural Sciences, Fuzhou, China. \\ ${ }^{2}$ Fujian Academy of Agricultural Sciences, Fuzhou, China. \\ ${ }^{3}$ College of Life Sciences, Fujian Agriculture and Forestry University, Fuzhou, China.
}

Submitted: April 19, 2012; Approved: April 01, 2013.

\begin{abstract}
A field experiment established in 1980 was conducted to evaluate the effects of open drainage ditch applied for water removal on bacterial and fungal communities of cold waterlogged paddy soils in 2011. In this experiment, traditional plate counting and temperature gradient gel electrophoresis were employed to characterize the abundance and diversity of soil bacterial and fungal communities. Four different distances from the open drainage ditch, 5, 15, 25 and $75 \mathrm{~m}$ with different degrees of drainage were designed for this study. Maximum populations of culturable aerobic bacteria and fungi were at 15 -m distance while minimum populations were at 75 -m distance. Significant differences $(\mathrm{p}<0.05)$ in fungal populations were observed at all distances from open drainage ditch. The highest diversity of the bacterial community was found at a distance of $25 \mathrm{~m}$, while that of the fungal community was observed at a distance of $5 \mathrm{~m}$. Sequencing of excised TGGE bands indicated that the dominant bacteria at 75-m distance belonged to anaerobic or microaerobic bacteria. Relationships between microbial characteristics and soil physicochemical properties indicated that soil $\mathrm{pH}$ and available nitrogen contents were key factors controlling the abundance of culturable aerobic bacteria and fungi, while soil water capacity also affected the diversity of fungal community. These findings can provide the references for better design and advanced management of the drainage ditches in cold waterlogged paddy soils.
\end{abstract}

Key words: abundance, bacterial and fungal communities, diversity, open drainage ditch.

\section{Introduction}

Cold waterlogged paddy soils (CWPS) are a type of low-yield paddy field widely distributed in southern China. In Fujian Province, CWPS occupy about 128,000 hectares (ha), accounting for $12.0 \%$ of the total area of paddy fields, and about $47.7 \%$ of the total low-yield paddy area in the whole province (Li et al., 2011). Low productivity of cold waterlogged paddy (CWP) fields is attributed to their physical and chemical factors, such as high groundwater table, poor drainage conditions, low soil temperature, excessive amount of reducing substances, poor aeration conditions, and low contents of available nutrients (Cheng, 1984). Obviously, only through proper drainage can CWPS become favorable for rice growth. Once drained, excess water in ag- ricultural soils is rapidly removed, the moisture in paddy soil decreases greatly, and the groundwater table is lowered. Thus, drainage promotes cohesion of soil particles, increases bulk density and hardness of soil (Cheng, 1984), improves soil aeration conditions, and accelerates oxidation of soil organic matter (SOM) contents. Thereby, drainage which serves as an important water management strategy, not only improves the physical properties of paddy soils, but also promotes soil fertility.

In China, most farmers have conventionally employed some techniques for land drainage, such as open drainage ditch, mole drainage, tile drainage, and their combinations. Agricultural drainage ditches are essential for removal of surface and ground waters to allow for crop production in poorly drained agricultural landscapes (Nee- 
delman et al., 2007). Ditches range in size from small depressed channels designed primarily for carrying surface runoff to major channelized streams draining large watersheds and regional groundwater (Needelman et al., 2007). In fact, the ditches serve not only to prevent flooding so as to reduce crop stress through the rapid removal of excess water, but also to dry the soils to facilitate operation of farm machineries.

Although it is well known that drainage ditches can bring about noticeable shifts in soil quality and rice growth in poorly drained agricultural land, little is known as to their effect on soil microorganisms, which play the major role in soil ecosystems. Soil microbial function governs to mediate nutrient cycling, organic matter decomposition, and soil aggregate formation (Kamaa et al., 2011).

Good understanding of soil microbial communities will allow us to identify the relationships between ditch drainage, soil fertility and rice productivity. CWP field with an open drainage ditch was established in 1980 in the middle of paddy field in Shunchang, Fujian Province in China. Thus, this study aimed to use cultivation-dependant method and molecular techniques, including DNAextraction and PCR/TGGE-analysis, to characterize the abundance and diversity of soil bacterial and fungal communities at four different distances from open drainage ditch.

\section{Materials and Methods}

\section{Site descriptions and soil samplings}

The study site is located at the Shunchang Long-Term Experimental Station (LTES, since 1980) of ColdWaterlogged Field Improvement, Fujian Academy of Agricultural Sciences $\left(26^{\circ} 42^{\prime} \mathrm{N}, 117^{\circ} 42^{\prime} \mathrm{E}\right)$, Fujian Province, China. The elevation of the LTES is $262 \mathrm{~m}$ above sea level. It has subtropical monsoon humid climate with annual average temperature of $18.5^{\circ} \mathrm{C}$, precipitation of $1691.3 \mathrm{~mm}$ and sunshine of $2,292 \mathrm{~h}$. The CWPS is derived from quaternary sediment and classified as a type of gleyic paddy soil. To transport excess water from paddy soils, an open drainage ditch $(200 \mathrm{~m}$ in length, $300 \mathrm{~cm}$ in bottom width, $1.0 \mathrm{~m}$ in depth) was established in the middle of paddy field in 1980. Dig a trench using the shovel in the ground of cold waterlogged paddy field, filled the bottom of the trench with large stones, set large stones outside and crushed stones insides the sides of trench, laid a $40-\mathrm{cm}$ layer of soil over the stones on both sides of the planned trench (Figure 1). Four distances were selected for soil samplings, which were located at $5,15,25$ and $75 \mathrm{~m}$, respectively, away from the open ditch (Figure 1). Surface soil samples (i.e., 0-20 cm) were collected from each plot in March 2011 during slack winter season. Three plots at each distance were collected and three soil cores (approx. $6 \mathrm{~cm}$ in diameter) taken from each plot were mixed to generate a composite sample. A total of 12 composite samples were obtained

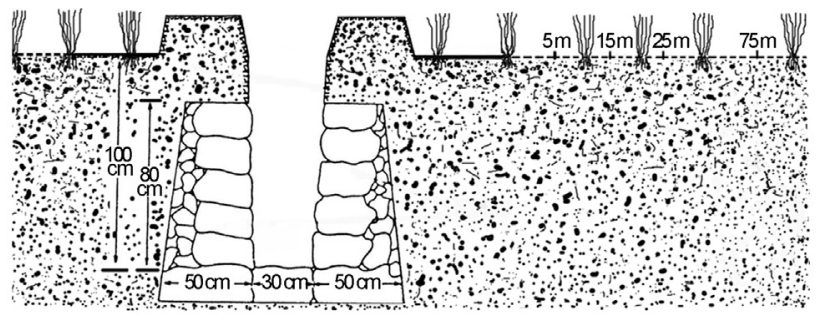

Figure 1 - Open drainage ditch and sampling sites.

for this study. They were designed as follows: 5I, 5II, 5III, 15I, 15II, 15III, 25I, 25II, 25III, 75I, 75I, and 75III, according to the sampling distance. These soil samples were transferred into ziplock plastic bags and stored at $4{ }^{\circ} \mathrm{C}$ until analyzed.

\section{Soil analyses}

Soil $\mathrm{pH}$ was measured with a $\mathrm{pH}$ meter using a soil to water of 1:2.5 suspensions (Metter-Toledo EL20K) (Thomas, 1996). Soil organic matter (SOM) was determined by $\mathrm{K}_{2} \mathrm{Cr}_{2} \mathrm{O}_{7}$ oxidation-reduction titration method (Walkley and Black, 1934). Available N (AN) and available P (AP) were determined by $\mathrm{NaOH}$ hydrolyzable and molybdemum methods, respectively. Available K (AK) was determined using atomic absorption spectrometer (AAS, SP-3801, Shanghai-Spectrum, Shanghai, China) (Jackson, 1979). Soil water content (SWC) was measured gravimetrically, drying soil $\left(10 \mathrm{~g}\right.$ ) in an oven at $105^{\circ} \mathrm{C}$ for $24 \mathrm{~h}$ (Zhang et al., 2011).

\section{Plate counting of soil microorganisms}

10 -fold serial dilutions of soil suspensions were prepared for spread plate counting. $10^{-3}-10^{-5}$ dilutions were used for bacteria counting with beef extract peptone medium (Jiang et al., 1995), and $10^{-2}-10^{-4}$ dilutions were prepared for fungi counting with rose bengal medium (Smith and Dawson, 1944). Plates with $0.1 \mathrm{~mL}$ of inoculum were inverted and incubated at $28 \pm 2{ }^{\circ} \mathrm{C}$ for $3 \mathrm{~d}$ for bacteria and $5 \mathrm{~d}$ for fungi. After incubation, a plate with a countable number of colonies (between 30 and 300) was selected. The number of colonies was counted and the number of microbes in $1 \mathrm{~g}$ of dry soil was calculated.

\section{DNA extraction from soils and PCR amplification}

Soil DNA was extracted using the SDS-based DNA extraction method(Zhou et al., 1996). For bacteria, the 16S rDNA V3 fragments were amplified using the fD1/rD1 (Weisburg et al., 1991) and F341GC/R534 (Muyzer et al., 1993) primers with nested PCR. Amplification using primer pair $\mathrm{fD} 1 / \mathrm{rD} 1$ was performed in $50-\mu \mathrm{L}$ reaction mixtures, including $5 \mu \mathrm{L} 10 \times$ PCR buffer with $\left(\mathrm{NH}_{4}\right)_{2} \mathrm{SO}_{4}, 3 \mathrm{~L}$ $25 \mathrm{mM} \mathrm{MgCl}_{2}$, and $4 \mu \mathrm{L} 2.5 \mathrm{mM}$ dNTPs. Then, $0.5 \mu \mathrm{L}$ Taq

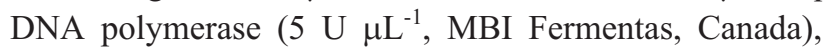
$1 \mu \mathrm{L} 20 \mu \mathrm{M}$ each primer, $1 \mu \mathrm{L}$ DNA template (10-50 ng) 
were prepared. A touchdown PCR strategy was employed as follows: 5 min at $94{ }^{\circ} \mathrm{C}, 20$ cycles of 1 min at $94{ }^{\circ} \mathrm{C}, 45 \mathrm{~s}$ at temperatures decreasing from $65^{\circ} \mathrm{C}$ to $55^{\circ} \mathrm{C}, 2 \mathrm{~min}$ at $72{ }^{\circ} \mathrm{C}, 10$ cycles of $1 \mathrm{~min}$ at $94{ }^{\circ} \mathrm{C}, 45 \mathrm{~s}$ at $55^{\circ} \mathrm{C}, 2$ min at $72^{\circ} \mathrm{C}$, and final extension for $5 \mathrm{~min}$ at $72^{\circ} \mathrm{C}$. PCR amplification of a 16S rDNA V3 fragment using primer pair F341GC/R534 was carried out in a $25 \mu \mathrm{L}$ containing $2.5 \mu \mathrm{L}$ PCR buffer, $1.5 \mu \mathrm{L} \mathrm{MgCl}_{2}, 2.8 \mu \mathrm{L}$ dNTPs, $0.5 \mu \mathrm{L}$ Taq DNA polymerase, $0.5 \mu \mathrm{L}$ each primer, $1 \mu \mathrm{L}$ DNA template (Amplicons resulted from fD1/rD1 were diluted 1:100). Concentrations of PCR components and cycling conditions were the same as above. For fungi, fragments of $18 \mathrm{~S}$ rRNA gene were amplified with primer pair FR1-GC/FF390 as described by Vainio and Hantula (2000). All PCR components $(50 \mu \mathrm{L})$ were the same as $\mathrm{fD} 1 / \mathrm{rD} 1$ reactions except for PCR buffer $(10 \mathrm{x}$ buffer with $\mathrm{KCl})$ and primer pair. The PCR procedure was as follows: $3 \mathrm{~min}$ at $95^{\circ} \mathrm{C}$, then 35 cycles of $30 \mathrm{~s}$ at $95^{\circ} \mathrm{C}, 45 \mathrm{~s}$ at $50^{\circ} \mathrm{C}, 1 \mathrm{~min}$ at $72^{\circ} \mathrm{C}$, and final extension for $10 \mathrm{~min}$ at $72{ }^{\circ} \mathrm{C}$ (Beauregard et al., 2010). All reactions were carried out using a Whatman Biometra T1 96well Thermocycler. Primer sequences are listed in Table 1.

\section{TGGE and diversity measurements}

PCR products were loaded on 0.45 -mm thick $8 \%$ denaturing gels $(8 \%$ polyacrylamide gel $(\mathrm{Acr} / \mathrm{Bis}=37.5: 1), 1$ $\mathrm{x}$ TAE (40 mM Tris-Cl, $1 \mathrm{mM}$ EDTA), $2 \%$ glycerol, and $8 \mathrm{M}$ urea). TGGE was performed using a TGGE system (Whatman Biometra, Germany). All gels were run at $130 \mathrm{~V}$ for $3 \mathrm{~h}$ with $1 \mathrm{x}$ TAE buffer. Temperature gradient was optimized at $56-69^{\circ} \mathrm{C}$ for bacteria and $49-61{ }^{\circ} \mathrm{C}$ for fungi. After electrophoresis, gels were silver-stained using the procedures devised by Bassam and Caetano-Anollés (1993). Gel images were captured using the Cannon camera and analyzed by the Bio-rad Quantity One software. The diversity indices, including richness index and Shannon index, were calculated according to TGGE patterns, respectively. Each resolved band was considered as a specific phylotype. The pixel intensity of each band detected by Quantity One software represented the abundance of a specific phylotype for diversity estimations. The Shannon-Weaver indices $\left(H^{\prime}\right)$
(Shannon and Weaver, 1963) were calculated using the following Eq. (1):

$$
H^{\prime}=-\Sigma p_{i} \ln p_{i}
$$

where $p_{i}=n_{i} / \Sigma n, n_{i}$ is the abundance of the $i$ th phylotype per lane, and $\Sigma \mathrm{n}$ is the total abundance of all phylotypes per lane. In theory, $H^{\prime}$ values range from 0 (only one species present in the sample) to 5 (all species in the sample are represented by the same number of individuals), but in fact, $H^{\prime}$ values usually lie between 1.5 and 3.5 for ecological data and rarely exceed 4.0 (Seaby and Henderson, 2006). In general, more disturbed and less stable environments have lower $H^{\prime}$ values.

Finally, cluster analysis according to the TGGE patterns was employed to produce the dendrograms by the unweighted pair-group method with arithmetic average (UPGMA) method using Quantity One software.

\section{S/18S rRNA genes sequence determination}

The dominant bands in the TGGE gels with the same mobility were excised, incubated overnight in $10 \mathrm{mM}$ Tris- $\mathrm{HCl}(\mathrm{pH}$ 8.0) to elute DNA, re-amplified as described above, and electrophoresed with TGGE. Band excision, PCR, and TGGE were repeated until a single band was present. PCR products generated from TGGE bands were amplified with primers without GC-clamp at the 5'-end. Purified PCR products were ligated into the pMD19-T vector (TaKaRa Biotechnology, Dalian, China) according to the manufacturer's instructions. Four positive clones per band were used for DNA sequencing. The obtained partial environmental 16S/18S rRNA gene sequences were deposited in the European Nucleotide Archive database under accession numbers HE867098-HE867106 and compared to the sequences in NCBI GenBank database using the BLAST 2.2 program.

\section{Statistical analysis}

One-way ANOVA was employed to analyze the difference of all indices at each distance. Post hoc tests for each variable were made using LSD comparisons. The Pearson correlation analysis was utilized to determine the correlations between all the measured parameters. Signifi-

Table 1 - Primer used in this study.

\begin{tabular}{lclc}
\hline Target group & Primer & Sequence $\left(5^{\prime} \rightarrow 3^{\prime}\right)$ & Length of amplicon $(\mathrm{bp})$ \\
\hline Bacteria & $\mathrm{fD} 1$ & GAGTTTGATCCTGGCTCAG & 1533 \\
& rD1 & AGAAAGGAGGTGATCCAGCC & \\
& F341GC & GC clamp ${ }^{\text {a }}$ - CCTACGGGAGGCAGCAG & 234 \\
Fungi & R534 & ATTACCGCGGCTGCTGG & \\
& FR1-GC & GC clamp ${ }^{\text {- }}$ - AICCATTCAATCGGTAIT & 430 \\
& FF390 & CGATAACGAACGAGACCT & \\
\hline
\end{tabular}

${ }^{a}$ GC clamp represents CGC CCG CCG CGC GCG GCG GGC GGG GCG GGG GCA CGG GGG G.

${ }^{b} \mathrm{GC}$ clamp represents CCC CCG CCG CGC GCG GCG GGC GGG GCG GGG GCA CGG GCC G. 
cant differences for all statistical tests were evaluated at the level of $p \leq 0.05$ unless noted otherwise. All data analyses were conducted with the SPSS software (SPSS for Windows, Version 13.0, Chicago, IL).

\section{Results}

\section{Soil chemical properties and number of microbes in} relation to distance

$\mathrm{pH}$ of all soils were slight acid. SWC and SOM contents ranged from 58.5 to $70.6 \%$ and from 3.03 to $4.64 \%$, respectively (Table 2). From ANOVA analysis, soil pH, AN and AK contents decreased gradually with increasing distance from the open drainage ditch and were significantly greater $(\mathrm{p}<0.05)$ at $5-\mathrm{m}$ than that at $75-\mathrm{m}$ distance. SOM contents were the lowest at $25 \mathrm{~m}$ distance and the highest at $75-\mathrm{m}$ distance. SWC increased gradually with increasing distance and was significantly lower at $5-\mathrm{m}$ than the other distances $(p<0.05)$. There were no significant differences $(p<0.05)$ in soil AP contents detected at all distances. The highest populations of culturable aerobic bacteria and fungi were at $15-\mathrm{m}$ distance and the lowest at $75-\mathrm{m}$ distance. Moreover, significant differences $(p<0.05)$ in fungi populations were also observed at all distances.

According to Pearson's correlation analyses, the numbers of culturable aerobic bacteria and fungi showed significantly positive correlation with soil $\mathrm{pH}$ (i.e., $\mathrm{R}=0.669, \mathrm{p}<0.05$ and $\mathrm{R}=0.730, \mathrm{p}<0.01$, respectively) and $\mathrm{AN}$ contents (i.e., $\mathrm{R}=0.741, \mathrm{p}<0.01$, and $\mathrm{R}=0.721$, $\mathrm{p}<0.01$, respectively) but not with SWC, SOM and AP contents (Table 3 ). In addition, fungi counts also showed significantly positive correlation with AK contents (i.e., $\mathrm{R}=0.844, \mathrm{p}<0.01)$.

\section{Microbial community structure associated with ditch distance}

TGGE analysis was performed using three replicate samples from each distance in the CWP field. TGGE results demonstrated that the number of bands in eubacterial $16 \mathrm{~S}$ rDNA amplified fragment was higher than that in fungal $18 \mathrm{~S}$ rDNA amplified fragment from all distances except for 5-m distance (Figure 2). For bacteria, TGGE patterns showed regular changes associated with the distance from the open drainage ditch. Some bands (Figure 2a, from 1B to 7B) of 16S rRNA gene gradually became stronger with increase in distance, but some others gradually turned fainter such as band $1 \mathrm{~b}$, and even disappeared such as band $2 \mathrm{~b}$ and $3 \mathrm{~b}$ (Figure 2a). However, the TGGE profile of fungi showed abrupt shift from 5-m to 15-m distance. 18 rRNA gene bands were abundant at a distance of $5 \mathrm{~m}$, but few at distances of $15 \mathrm{~m}, 25 \mathrm{~m}$ and $75 \mathrm{~m}$. Moreover, there were some specific bands at a certain distance, such as $1 \mathrm{~F}$ (Figure $2 \mathrm{~b}$ ) at $75 \mathrm{~m}$, and $2 \mathrm{~F}$ at $25 \mathrm{~m}$ (Figure $2 \mathrm{~b}$ ).

Cluster analyses of the TGGE profiles generally distinguished the bacterial and fungal communities into two major clusters (Figure 3). In the bacterial community, those soils at distances of 5,15 and $25 \mathrm{~m}$ with relatively similar banding patterns clustered together, but those at $75-\mathrm{m}$ distance formed another cluster (Figure 3a). The dendrogram of clustering for the fungal community was distinctly different from that for the bacterial community. Those soil

Table 2 - Average of soil properties, soil available nutrients and microbial populations at different sampling sites.

\begin{tabular}{lcccccccc}
\hline Site & $\mathrm{pH}$ & SWC (\%) & SOM $(\%)$ & AN $(\mathrm{mg} / \mathrm{kg})$ & AP $(\mathrm{mg} / \mathrm{kg})$ & AK $(\mathrm{mg} / \mathrm{kg})$ & Bacteria $\left(10^{4} \mathrm{cfu} / \mathrm{g}\right)$ & Fungi $\left(10^{3} \mathrm{cfu} / \mathrm{g}\right)$ \\
\hline $5 \mathrm{~m}$ & $6.73 \pm 0.10 \mathrm{a}^{*}$ & $58.5 \pm 2.2 \mathrm{~b}$ & $3.87 \pm 0.27 \mathrm{ab}$ & $159.4 \pm 9.4 \mathrm{a}$ & $6.72 \pm 4.06 \mathrm{a}$ & $51.6 \pm 15.7 \mathrm{a}$ & $10.60 \pm 1.09 \mathrm{ab}$ & $3.94 \pm 0.82 \mathrm{~b}$ \\
$15 \mathrm{~m}$ & $6.570 .25 \mathrm{ab}$ & $68.0 \pm 6.8 \mathrm{a}$ & $3.61 \pm 1.36 \mathrm{ab}$ & $152.821 .8 \mathrm{ab}$ & $2.95 \pm 0.41 \mathrm{a}$ & $48.5 \pm 9.4 \mathrm{a}$ & $13.61 \pm 4.39 \mathrm{a}$ & $4.88 \pm 0.29 \mathrm{a}$ \\
$25 \mathrm{~m}$ & $6.12 \pm 0.21 \mathrm{bc}$ & $69.5 \pm 4.9 \mathrm{a}$ & $3.03 \pm 0.18 \mathrm{~b}$ & $130.2 \pm 12.4 \mathrm{bc}$ & $3.13 \pm 0.23 \mathrm{a}$ & $37.8 \pm 15.7 \mathrm{a}$ & $7.98 \pm 1.75 \mathrm{bc}$ & $2.60 \pm 0.39 \mathrm{c}$ \\
$75 \mathrm{~m}$ & $5.79 \pm 0.47 \mathrm{c}$ & $70.6 \pm 3.7 \mathrm{a}$ & $4.64 \pm 0.18 \mathrm{a}$ & $111.3 \pm 13.2 \mathrm{c}$ & $3.04 \pm 1.60 \mathrm{a}$ & $12.7 \pm 0.0 \mathrm{~b}$ & $5.16 \pm 0.27 \mathrm{c}$ & $0.23 \pm 0.05 \mathrm{~d}$ \\
\hline
\end{tabular}

*Values are given as means \pm S.D. $(n=3)$; values within a column followed by different lowercase letters are significantly different $(n=3, L S D, p<0.05)$.

Table 3 - Pearson's correlation between soil properties, soil available nutrients and microbial populations.

\begin{tabular}{|c|c|c|c|c|c|c|c|c|}
\hline & $\mathrm{pH}$ & SWC (\%) & $\operatorname{SOM}(\%)$ & $\mathrm{AN}(\mathrm{mg} / \mathrm{kg})$ & $\mathrm{AP}(\mathrm{mg} / \mathrm{kg})$ & $\mathrm{AK}(\mathrm{mg} / \mathrm{kg})$ & Bacteria $\left(10^{4} \mathrm{cfu} / \mathrm{g}\right)$ & Fungi $\left(10^{3} \mathrm{fu} / \mathrm{g}\right)$ \\
\hline pH SWC & $1.000-0.590^{*}$ & 1.000 & & & & & & \\
\hline SOM & -0.073 & -0.205 & 1.000 & & & & & \\
\hline $\mathrm{AN}$ & $0.763^{* *}$ & -0.549 & 0.080 & 1.000 & & & & \\
\hline $\mathrm{AP}$ & 0.325 & -0.399 & 0.151 & 0.409 & 1.000 & & & \\
\hline $\mathrm{AK}$ & $0.667^{*}$ & -0.453 & -0.365 & $0.610^{*}$ & 0.508 & 1.000 & & \\
\hline Bacteria & $0.669^{*}$ & -0.459 & -0.103 & $0.741^{* *}$ & 0.122 & 0.497 & 1.000 & \\
\hline Fungi & $0.730^{* *}$ & -0.379 & -0.442 & $0.721^{* *}$ & 0.181 & $0.844^{* *}$ & $0.749^{* *}$ & 1.000 \\
\hline
\end{tabular}

${ }^{*}$ Significant at the 0.05 level; ${ }^{* *}$ significant at the 0.01 level. 
a

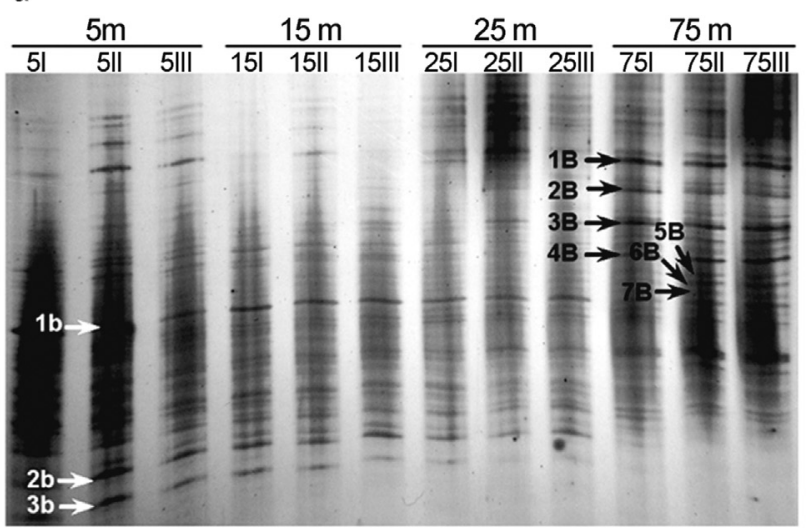

b

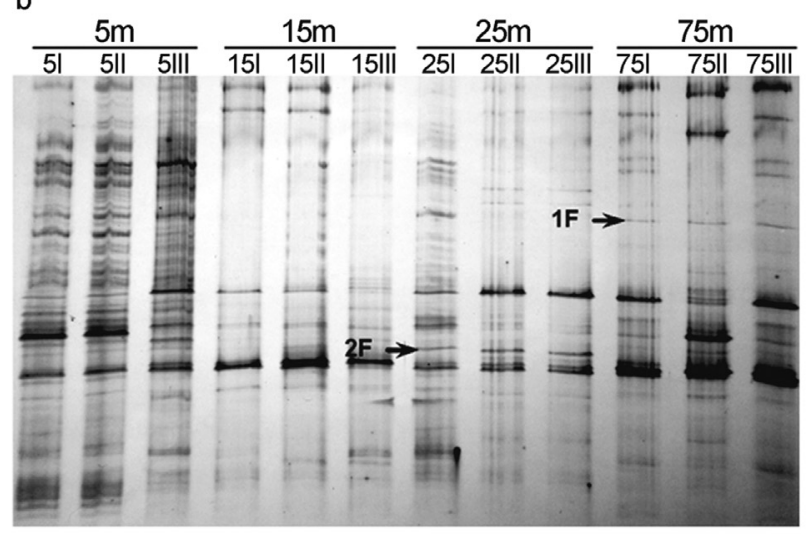

Figure 2 - TGGE profiles of (a) 16S rRNA and (b) 18S rRNA gene of soil samples at different distances.

samples at distances of 15, 25 and $75 \mathrm{~m}$, except for sample 25I, were assigned to one cluster, while those at $5-\mathrm{m}$ distance and sample 25I were detected in another cluster (Figure 3b). The richness and Shannon indices for bacteria and fungi both showed the minimum values at $15-\mathrm{m}$ distance (Table 4). The bacterial and fungal Shannon-Weaver indices $\left(H^{\prime}\right)$ at four distances ranged from 2.772 to 3.071 and from 2.055 to 3.148 , respectively (Table 4 ). The highest diversity $\left(H^{\prime}=3.071\right)$ of bacterial community was found at a distance of $25 \mathrm{~m}$, while that $\left(H^{\prime}=3.148\right)$ of the fungal community was observed at a distance of $5 \mathrm{~m}$, which was significantly different from the diversity at the other distances $(\mathrm{p}<0.05$, Table 4).

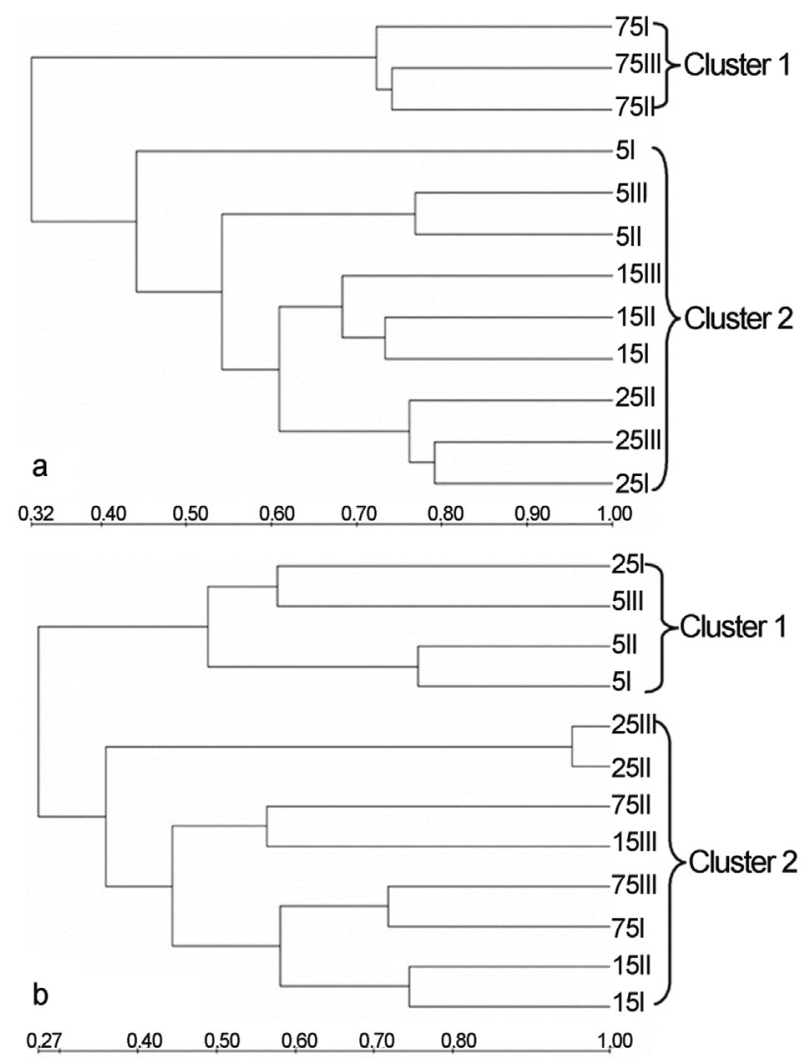

Figure 3 - Cluster analysis of TGGE fingerprints from the gels in Figure 2. (a) 16S rRNA and (b) 18S rRNA gene.

\section{Nucleotide sequencing and analysis}

Seven dominant bacterial bands (1B, 2B, 3B, 4B, 1b, $2 \mathrm{~b}$, and $3 \mathrm{~b})$ in Figure $2 \mathrm{a}$ and two specific fungal bands $(1 \mathrm{~F}$ and $2 \mathrm{~F}$ ) in Figure $2 \mathrm{~b}$ were excised for sequence analysis. The BLAST analysis of the 16S rDNA sequences derived from TGGE gel bands classified these sequences into six main groups: Chloroflexi (1B), Deltaproteobacteria (2B), Acidobacteria (3B and 3b), Betaproteobacteria (4B), Gammaproteobacteria (1b) and Alphaproteobacteria (2b) (Table 5). Furthermore, band 2B was highly similar to the Geobacteraceae (96\%) which was the closest cultivated relative of hits in GenBank database, and band $4 \mathrm{~B}$ was highly similar to the cultivated relative Curvibacter sp.

Table 4 - Comparison of microbial diversity indices at different sampling sites.

\begin{tabular}{lccccc}
\hline \multirow{2}{*}{ Treatment } & \multicolumn{2}{c}{ Richness } & & \multicolumn{2}{c}{ Shannon $(H)$} \\
\cline { 2 - 3 } \cline { 5 - 6 } & Bacteria & Fungi & & Bacteria & Fungi \\
\hline $5 \mathrm{~m}$ & $31 \pm 1 \mathrm{a}^{*}$ & $38 \pm 3 \mathrm{a}$ & & $2.886 \pm 0.126 \mathrm{~b}$ & $3.148 \pm 0.098 \mathrm{a}$ \\
$15 \mathrm{~m}$ & $29 \pm 3 \mathrm{~b}$ & $15 \pm 4 \mathrm{~b}$ & & $2.772 \pm 0.109 \mathrm{~b}$ & $2.055 \pm 0.225 \mathrm{~b}$ \\
$25 \mathrm{~m}$ & $32 \pm 1 \mathrm{a}$ & $21 \pm 10 \mathrm{~b}$ & & $3.071 \pm 0.023 \mathrm{a}$ & $2.149 \pm 0.754 \mathrm{~b}$ \\
$75 \mathrm{~m}$ & $30 \pm 1 \mathrm{a}$ & $18 \pm 4 \mathrm{~b}$ & & $2.917 \pm 0.053 \mathrm{ab}$ & $2.244 \pm 0.113 \mathrm{~b}$ \\
\hline
\end{tabular}

${ }^{*}$ Values are given as means \pm S.D. $(n=3)$; values within a column followed by different lowercase letters are significantly different $(n=3, L S D, p<0.05)$. 
Table 5 - Tentative identification of dominant TGGE bands in TGGE gels and the closet match to the sequence from GenBank database with BLAST.

\begin{tabular}{|c|c|c|c|c|c|c|c|}
\hline $\begin{array}{l}\text { Clone (accession } \\
\text { no.) }\end{array}$ & $\begin{array}{c}\text { Dominant } \\
\text { habitat }\end{array}$ & $\begin{array}{l}\text { Phylogenetic } \\
\text { group }^{\mathrm{a}}\end{array}$ & $\begin{array}{l}\text { Closest relative } \\
{\text { (accession no. })^{\mathrm{b}}}^{\text {accion }}\end{array}$ & Isolation source & $\begin{array}{l}\text { Identity } \\
(\%)\end{array}$ & $\begin{array}{l}\text { Closest cultivated relative } \\
\quad(\text { accession no. })^{c}\end{array}$ & Identity $(\%)$ \\
\hline 1B (HE867098) & 75-m distance & Chloroflexi & UB (HQ636245) & Lake sediment & 100 & - & - \\
\hline 2B (HE867099) & 75-m distance & $\delta$-Proteobacteria & UB (HM487998) & Lake sediment & 99 & Geobacteraceae (EF059536) & 96 \\
\hline 3B (HE867100) & 75-m distance & Acidobacteria & UB (AB660646) & Rice paddy soil & 100 & - & - \\
\hline 4B (HE867101) & 75-m distance & $\beta$-Proteobacteria & UB (HM535093) & Wetland soil & $\underline{99}$ & $\frac{\text { Curvibacter sp. ATCC }}{700892(\mathrm{HM} 357758)}$ & 98 \\
\hline 1b (HE867102) & $\begin{array}{l}\text { 5-m distance } \\
25-\mathrm{m} \text { distance }\end{array}$ & $\gamma$-Proteobacteria & UB (EU298759) & Prairie soil & 99 & - & - \\
\hline 2b (HE867103) & $\begin{array}{l}\text { 5-m distance } \\
25-\mathrm{m} \text { distance }\end{array}$ & $\alpha$-Proteobacteria & UB (JQ649765) & Polluted soil & 100 & - & - \\
\hline 3b (HE867104) & 5-m distance & Acidobacteria & UB (HQ597366) & Grassland soil & 99 & - & - \\
\hline 1F (HE867105) & 75-m distance & Chytridiomycota & UE (JQ689413) & Eutrophic lake & 99 & $\frac{\text { Chytriomyces poculatus }}{(\mathrm{EF} 443135)}$ & 98 \\
\hline 2F (HE867106) & 25-m distance & Zygomycota & UE (AY689723) & $\begin{array}{l}\text { Stream sedi- } \\
\text { ments }\end{array}$ & 99 & $\frac{\text { Lepidostroma rugaramae }}{(\mathrm{FJ} 171731)}$ & 89 \\
\hline
\end{tabular}

${ }^{a} \alpha$, alpha; $\beta$, beta; $\gamma$, gamma; $\delta$, delta.

${ }^{b} U B$ represents uncultured bacterium.

c“--"represents no closest cultivated hit in GenBank.

ATCC 700892 (98\%), while other bacterial bands had no similar cultivated hits in GenBank database (Table 5). The two fungal $18 \mathrm{~S}$ rDNA sequences fell within the phylum Chytridiomycota (1F) and Zygomycota (2F), respectively (Table 5). Base on the closest cultivated hit of GenBank database, bands $1 \mathrm{~F}$ and $2 \mathrm{~F}$ were similar to Chytriomyces poculatus $(98 \%)$ and Lepidostroma rugaramae $(89 \%)$, respectively (Table 5).

Noticeably, the bacterial bands (1B, 2B, 3B, and 4B) in Figure 2a getting stronger and stronger from good drainage $(5 \mathrm{~m})$ to poor drainage $(75 \mathrm{~m})$ and finally leading to dominant microorganisms at $75-\mathrm{m}$ distance, were most similar to the sequences retrieved from waterlogged environments or flooding zones, like lake sediment, rice paddy soil, wetland and etc (Table 5). However, bands $1 \mathrm{~b}, 2 \mathrm{~b}$ and $3 \mathrm{~b}$ in Figure 2a gradually turning fainter or disappeared with increase in distance started from the open drainage ditch, were most similar to the organisms found in grassland soil and dry land without water logging (Table 5). Furthermore, the specific $18 \mathrm{~S}$ rDNA sequences $(1 \mathrm{~F}$ and $2 \mathrm{~F}$ ) derived from dank soils of 25-m and 75-m distances in Fig- ure $2 \mathrm{~b}$ were highly similar (>96\%) to microorganisms in aquatic environments like eutrophic lake, stream sediment (Table 5).

\section{Relationships between microbial diversity indices and other parameters}

The correlation analyses indicated that the richness indices and Shannon indices of fungi were negatively correlated with $\mathrm{SWC}$ (i.e., $\mathrm{R}=-0.667, \mathrm{p}<0.05$ and $\mathrm{R}=-0.655$, $\mathrm{p}<0.05$, respectively, Table 6), but those of bacteria were not. In addition, the richness indices of fungi was positively correlated with AP contents (i.e., $\mathrm{R}=0.581, \mathrm{p}<0.05$, Table 6). The Shannon indices of both bacteria and fungi showed significant positive correlation with the TGGE's band number (i.e., $\mathrm{R}=0.648, \mathrm{p}<0.05$ and $\mathrm{R}=0.954$, $\mathrm{p}<0.01$, respectively, Table 6), but not with the number of culturable cells in Table 2 .

\section{Discussion}

Although many studies on the effects of agricultural management practices on soil microbial communities have

Table 6 - earson's correlation between microbial diversity indices, soil properties and soil available nutrients.

\begin{tabular}{lcccccccccc}
\hline & $\mathrm{pH}$ & $\mathrm{SWC}(\%)$ & $\mathrm{SOM}(\%)$ & $\mathrm{AN}(\mathrm{mg} / \mathrm{kg})$ & $\mathrm{AP}(\mathrm{mg} / \mathrm{kg})$ & $\mathrm{AK}(\mathrm{mg} / \mathrm{kg})$ & $16 \mathrm{~S} \mathrm{R}^{\mathrm{a}}$ & $18 \mathrm{~S} \mathrm{R}^{\mathrm{a}}$ & $16 \mathrm{~S} \mathrm{H}^{\mathrm{b}}$ & $18 \mathrm{~S} \mathrm{H}^{\mathrm{b}}$ \\
\hline $16 \mathrm{~S} \mathrm{R}$ & -0.101 & -0.264 & -0.355 & -0.123 & -0.014 & -0.173 & 1.000 & - & - \\
$18 \mathrm{~S} \mathrm{R}$ & 0.439 & $-0.667 *$ & 0.096 & 0.432 & $0.581^{*}$ & 0.361 & 0.159 & 1.000 & - & - \\
$16 \mathrm{~S} \mathrm{H}$ & -0.333 & 0.033 & -0.106 & -0.349 & 0.227 & -0.129 & $0.648^{*}$ & 0.021 & 1.000 & - \\
$18 \mathrm{~S} \mathrm{H}$ & 0.456 & $-0.655^{*}$ & 0.165 & 0.329 & 0.539 & 0.300 & 0.086 & $0.954^{* *}$ & -0.033 & 1.000 \\
\hline
\end{tabular}

*Significant at the 0.05 level; ${ }^{* *}$ significant at the 0.01 level.

${ }^{a}$ represents Richness index.

${ }^{b}$ represents Shannon index. 
focused on irrigation pattern, fertilization regime, and tillage system (Zhang et al., 2008; Beauregard et al., 2010; Ceja-Navarro et al., 2010; Islam et al., 2011; Kamaa et al., 2011; Yang et al., 2011), only few studies have been done on ditch drainage. Ditch drainage with associated changes in soil properties led to distinct shifts of abundance and structure of bacterial and fungal communities, which significantly affected the soil ecosystem. Ditch drainage caused decrease in soil $\mathrm{pH}$ with increasing distance away from the open ditch (Table 2). Soil pH was one of the most influential factors in soil (Rousk et al., 2010), and strongly affected all chemical, physical and biological soil properties (Andersson et al., 2000; Brady and Weil, 2002; Jones et al., 2009; Rousk et al., 2009), which were further confirmed by our studies. Soil $\mathrm{pH}$ was shown to have significant positive correlation with contents of soil AN $(\mathrm{R}=0.763, \mathrm{p}<0.01), \mathrm{AK}(\mathrm{R}=0.667, \mathrm{p}<0.05)$, and numbers of viable bacteria and fungi cells $(R=0.669, p<0.05$ and $\mathrm{R}=0.730, \mathrm{p}<0.01$, respectively, Table 3 ).

Soil microbial abundance is strongly influenced by soil physical and chemical properties (Hrelová et al., 1999; Kobarli et al., 2010; Hong et al., 2011), including soil texture, soil aggregate, soil $\mathrm{pH}$, and soil nutrient. However, all of these soil factors can be altered by changes of agricultural managements. In our study, drainage led to obvious change in all detected parameters except for AP along distance from the ditch. Among the detected parameters, soil $\mathrm{pH}$ and $\mathrm{AN}$ content were significantly and positively correlated with culturable aerobic bacterial counts and fungal counts, suggesting that both soil $\mathrm{pH}$ and $\mathrm{AN}$ content had marked influence on the growth of bacteria and fungi. Our findings were consistent with those of Brodie et al. (2002) that soil physicochemical factors, such as soil $\mathrm{pH}$ or $\mathrm{AN}$ content were the principal determinants controlling bacterial community in a field situation. In addition, AK content was significantly and positively correlated with fungi counts, indicating that soil AK content had an important impact on the abundance of culturable fungi in CWPS.

TGGE analysis revealed that some bands (from 1B to 7B) of bacteria became stronger with increasing distance, but some others turned fainter or disappeared (from $1 \mathrm{~b}$ to 3b)(Figure 2a), which implied that some bacteria proliferated with increasing poor drainage, while some others were suppressed, e.g., at 75-m distance under poor drainage condition, minimum populations of culturable aerobic bacteria were found (Table 2). From good drainage $(5 \mathrm{~m})$ to poor drainage $(75 \mathrm{~m})$, some aerobic organisms become quiescent or die, and new inhabitants, possibly including facultative (organisms which can function under both aerobic and anaerobic environments) and obligate anaerobic bacteria, took over (Inglett et al., 2005). This was confirmed by the tentative identification of dominant TGGE bands in Table 5 , for instance, the $2 \mathrm{~B}$ band sequence was highly similar to the family Geobacteraceae, which were the obligate anaerobes predominating sedimentary environments (Snoeyen-
bos-West et al., 2000; Holmes et al., 2007), and the 4B band sequence was highly similar to Curvibacter sp. ATCC 700892 belonging to microaerobic bacteria (Ding and Yokota, 2010).

Eickhorst et al. (2010) mentioned soil fungal communities are the most important group of organisms involved in decomposing organic matter. In paddy soils, they are predominant only after drainage and during post-harvest fallow conditions as they need oxygen which is limited under flooded conditions. In our study, at 5-m distance with relatively good drainage conditions, the fungal communities were much more diverse than those at other distances with relatively poor drainage conditions (Figure $2 b$ ). Additionally, significant differences $(\mathrm{p}<0.05)$ of the diversity indices were noted between $5 \mathrm{~m}$ and other distances (Table 4). Furthermore, two clusters of fungal dendrogram clearly distinguished between 5-m and the other distances (Figure 3b). These results could be explained by the close relationship between SWC and ditch drainage, since the significant differences in SWC (Table 2) were identical with the fungal diversity indices (Table 4) and SWC was also significantly and positively correlated with the fungal diversity indices (Table 6).

In comparison with bacteria, fungi seemed to be more easily affected by soil factors. For instance, the fungal abundance was noticeably influenced not only by soil $\mathrm{pH}$ and $\mathrm{AN}$ content, but also by soil $\mathrm{AK}$, and fungal diversity was significantly affected by SWC and AP contents, while the bacteria diversity was not correlated with SWC and AP. These results suggested that fungal communities were more sensitive to soil factors than bacteria communities. Therefore, changes in fungal community structures in agricultural soil might possibly serve as a sensitive indicator for changes in soil quality due to agricultural management (Kennedy and Smith, 1995; Schneider et al., 2010).

Compared to poorly drained paddy soils at $75-\mathrm{m}$ distance, well drained soils at 5-m distance gave significantly higher values in soil available nutrients, culturable microbes (Table 2) and fungal diversity (Table 4), indicating the improvement of soil properties. In this experiment, the lack of knowledge of rice yields at four different distances was a weak point to judge the functioning of the drainage ditch. Therefore, further study should pay more attention to rice yields, soil characteristics, anaerobic microbial communities, draining rate and their relationships. It will help us know how to manage the drainage ditch.

\section{Acknowledgments}

This work was financially supported by the Special Fund (201003059-08) for Agro-scientific Research, China, the Doctoral Research Fund (2010BS-6) of Fujian Academy of Agricultural Sciences, China and the Natural Science Foundation (2011J05058) of Fujian Province, China. 


\section{References}

Andersson S, Nilsson I, Saetre P (2000) Leaching of dissolved organic carbon (DOC) and dissolved organic nitrogen (DON) in mor humus as affected by temperature and $\mathrm{pH}$. Soil Biol Biochem 32:1-10.

Bassam BJ, Caetano-Anollés G (1993) Silver staining of DNA in polyacrylamide gels. Appl Biochem Biotech 42:181-188.

Beauregard MS, Hamel C, St-Arnaud ANM (2010) Long-term phosphorus fertilization impacts soil fungal and bacterial diversity but not AM fungal community in alfalfa. Microb Ecol 59:379-389.

Brady NC, Weil RR (2002) The Nature and Properties of Soil. Springer, Netherlands.

Brodie E, Edwards S, Clipson N (2002) Bacterial community dynamics across a floristic gradient in a temperate upland grassland ecosystem. Microb Ecol 44:260-270.

Ceja-Navarro JA, Rivera FN, Patiño-Zúñiga L, Govaerts B, Marsch R, Vila-Sanjurjo A, Dendooven L (2010) Molecular characterization of soil bacterial communities in contrasting zero tillage systems. Plant Soil 329:127-137.

Cheng YS (1984) Effects of drainage on the characteristics of paddy soils in China. In: Banta, S., Mendoza, C.V.(eds). Organic Matter and Rice. International Rice Research Institute (IRRI), Los Banos, Philippines, pp 417-427.

Ding L, Yokota A (2010) Curvibacter fontana sp. nov., a microaerobic bacteria isolated from well water. J Gen Appl Microbiol 56:267-271.

Eickhorst T, Remesch M, Kuever J, Tippkötter R (2010) Molecular characterization of soil fungal communities in paddy soils. Proceedings of the 19th World Congress of Soil Science: Soil Solutions for a Changing World. Brisbane, Australia. 1-6, August 2010, 22-24. http://www.iuss.org/ 19th\%20WCSS/Symposium/pdf/1842.pdf.

Holmes DE, O'Neil RA, Vrionis HA, N'Guessan LA, OrtizBernad I, Larrahondo MJ, Adams LA, Ward JA, Nicoll JS, Nevin KP, Chavan MA, Johnson JP, Long PE, Lovley DR (2007) Subsurface clade of Geobacteraceae that predominates in a diversity of $\mathrm{Fe}(\mathrm{III})$-reducing subsurface environments. The ISME Journal 1:663-677.

Hong YG, Li M, Cao H, Gu JD (2011) Residence of Habitat-Specific Anammox Bacteria in the Deep-Sea Subsurface Sediments of the South China Sea: Analyses of Marker Gene Abundance with Physical Chemical Parameters. Microb Ecol 62:36-47.

Hrelová H, Chvátalová I, Vosátka M, Klír J, Gryndler M (1999). Correlation of abundance of arbuscular mycorrhizal fungi, bacteria and saprophytic microfungi with soil carbon, nitrogen and phosphorus. Folia Microbiol 44:683-587.

Inglett PW, Reddy KR, Corstanje R (2005) Anaerobic Soils. In: Hillel, D. (ed). Encyclopedia of Soils in the Environment. Academic Press, London, pp 72-78.

Islam MR, Puneet R, Chauhan S, Kim Y, Kim M, Sa TM (2011) Community level functional diversity and enzyme activities in paddy soils under different long-term fertilizer management practices. Biol Fertil Soils 47:599-604.

Jackson ML (1979) Soil Chemical Analysis. Wisconsin University, Madison, WI.

Jiang CJ, Chen PH, Shan S (1995) Total microcolony counting on the moving narrow culture band. J Microbiol Meth 23:297300 .
Jones RT, Robeson MS, Lauber CL, Hamady M, Knight R, Fierer N (2009) A comprehensive survey of soil acidobacterial diversity using pyrosequencing and clone library analyses. ISME J 3:442-453.

Kamaa M, Mburu H, Blanchart E, Chibole L, Chotte JL, Kibunja C, Lesueur D (2011) Effects of organic and inorganic fertilization on soil bacterial and fungal microbial diversity in the Kabete long-term trial, Kenya. Biol Fertil Soils 47:315-321.

Kennedy AC, Smith KL (1995) Soil microbial diversity and the sustainability of agricultural soils. Plant Soil 170:75-86.

Kobarli T, Fujii T, Kobari Y, Habano A (2010) Seasonal variations in abundance, growth and mortality of heterotrophic bacteria in Kagoshima Bay. J Oceanogr 66:845-853.

Li QH, Wang F, He CM, Lin C, Li Y, Lin XJ (2011) Formation, difficulties and utilization of cold water paddy fields in Fujian. Fujian J Agric Sci 26:681-685.

Muyzer G, De Waal EC, Uitterlinden AG (1993) Profiling of complex microbial populations by denaturing gradient gel electrophoresis analysis of polymerase chain reaction-amplified genes coding for 16S rRNA. Appl Environ Microbiol 59:695-700.

Needelman BA, Kleinman PJA, Strock JS, Allen AL (2007) Improved management of agricultural drainage ditches for water quality protection: An overview. J Soil Water Conserv 62:171-178.

Rousk J, Brookes PC, Bååth E (2009) Contrasting soil pH effects on fungal and bacterial growth suggests functional redundancy in carbon mineralisation. Appl Environ Microbiol 75:1589-1596.

Rousk J, Brookes PC, Bååth E (2010) Investigating the mechanisms for the opposing $\mathrm{pH}$ relationships of fungal and bacterial growth in soil. Soil Biol Biochem 42:926-934.

Schneider S, Hartmann M, Enkerli J, Widmer F (2010) Fungal community structure in soils of conventional and organic farming systems. Fungal Ecol 3:215-224.

Seaby RMH, Henderson PA (2006) Measuring and understanding biodiversity. http://www.piscesconservation.com.

Shannon C, Weaver W (1963) The Mathematical Theory of Communication. Illinois University Press, Urbana Champaign, IL.

Smith NR, Dawson VT (1944) The bacteriostatic action of rose Bengal in media used for the plate counts of soil fungi. Soil Sci 58:467-471.

Snoeyenbos-West OL, Nevin KP, Anderson, RT, Lovley DR (2000) Enrichment of Geobacter species in response to stimulation of $\mathrm{Fe}(\mathrm{III})$ reduction in sandy aquifer sediments. Microbial Ecol 39:153-167.

Thomas GW (1996) Soil pH and soil acidity. In: Sparks, DL, Page, AL, Helmke, PA, Loeppert, RH (eds) Methods of Soil Analysis. Soil Science Society of America, Madison, WI, pp 475-490.

Vainio EJ, Hantula J (2000) Direct analysis of wood-inhabiting fungi using denaturing gradient gel electrophoresis of amplified ribosomal DNA. Mycol Res 104:927-936.

Walkley A, Black LA (1934) An examination of the Degtjareff method of determing soil organic matter, and a proposed modification of the chromic acid titration method. Soil Sci 37:29-38.

Weisburg WG, Barns SM, Pelletier DA, Lane DJ (1991) 16S ribosomal DNA amplification for phylogenetic study. J Bacteriol 173:697-703. 
Yang SK, Kim MK, Seo WW, Choi KJ, Lee ST, Kwak YS, Lee YH (2011) Soil microbial community analysis of between no-till and tillage in a controlled horticultural field. World J Microb Biot doi:10.1007/s11274-011-0933-x.

Zhang SH, Chen DD, Sun DH, Wang XT, Smith JL, Du GZ (2011) Impacts of altitude and position on the rates of soil nitrogen mineralization and nitrification in alpine meadows on the eastern Qinghai-Tibetan Plateau, China. Biol Fertil Soils doi:10.1007/s00374-011-0634-5.
Zhang YL, Daib JL, Wang RQ, Zhang J (2008) Effects of longterm sewage irrigation on agricultural soil microbial structural and functional characterizations in Shandong, China Eur J Soil Biol 44:84-91.

Zhou JZ, Bruns MA, Tiedje JM (1996) DNA recovery from soils and diverse composition. Appl Environ Microbiol 62:316322.

All the content of the journal, except where otherwise noted, is licensed under a Creative Commons License CC BY-NC. 